\title{
Vulnerability of Tea Sector for Climate Change in the Major Tea Growing Regions in Central Hills of Sri Lanka
}

\author{
G. M. M. R. B. Karunaratne ${ }^{1, \#, ~ S . ~ P . ~ N i s s a n k a ~}{ }^{1}$, \\ B. V. R. Punyawardena ${ }^{2}$ and A. R. Gunawardena ${ }^{3}$ \\ ${ }^{1}$ Department of Crop Science, Faculty of Agriculture, \\ University of Peradeniya, Sri Lanka \\ ${ }^{2}$ Natural Resources Management Centre, \\ Department of Agriculture, Peradeniya, Sri Lanka \\ ${ }^{3}$ Central Environmental Authority, Battaramulla, Sri Lanka \\ ${ }^{\#}$ Corresponding Author: \\ Tele: (+94) 71323 9512; E-mail: rakkithakaru@gmail.com
}

\begin{abstract}
The climate change impacts are becoming a prominent issue in the Sri Lankan tea sector. This study has attempted to identify vulnerability of tea sector in the major tea growing district of Nuwara Eliya in the central hills of Sri Lanka. Mean monthly rainfall and temperature, drought conditions and soil erosion of Nuwara Eliya district were considered as major variables in climate vulnerability mapping. Climate vulnerability map was developed using weighted overlay modeling in Geographic Information Systems (GIS) by allocating appropriate weightages for the main variables mentioned above for their influence on tea production. Rainfall data analysis for the study period from 1945 to 2005 revealed significantly higher rainfall variability for months of January, June, July, and August, which highlights the need of special management attention in these months. Around 65\% of land extent of the study area possessed an ideal temperature regime $\left(18-25^{\circ} \mathrm{C}\right)$ for growth of tea. Land extent of 3.96\% under tea was highly vulnerable for soil erosion in the study area. Less and moderately soil erosion vulnerable tea extent were $79.64 \%$ and $16.40 \%$, respectively. The climate vulnerability map developed based on all four variables, revealed that $13.15 \%$ tea extent as highly vulnerable for current climate change. Land extent of $20.54 \%$ and $66.31 \%$ were categorized as moderately and less climate vulnerable, respectively, which could also become vulnerable in future, if present trends continues. Necessary adaptation strategies should therefore be implemented immediately to ensure the sustainability of the tea industry in the central hill region of Sri Lanka.
\end{abstract}

KEYWORDS: Climate change, Climate vulnerability, Climate vulnerability mapping, Geographic Information Systems (GIS) 


\section{Introduction}

Sri Lanka is an island whose economy is predominantly based on agriculture. Traditional peasant agriculture which had been continuing for centuries was replaced by large scale plantation agriculture in the mid- $18^{\text {th }}$ century. Exotic crops such as tea, rubber, coconut, coffee, and cocoa were intensively cultivated mainly in Wet (>2500 mm annual rainfall) and Intermediate (1750-2500 $\mathrm{mm}$ annual rainfall) zones of Sri Lanka. These plantation crops together with other agricultural crops contribute $10.6 \%$ to Gross Domestic Product (Central Bank of Sri Lanka, 2013). Out of those plantation crops, tea industry is playing a key role in social and economic stability in Sri Lanka. Total extent of tea plantations at present is 203,020 ha and more than 700,000 workers and their families are dependent on the tea industry (Plantation Sector Statistical Pocket Book, 2012).

However, currently the tea sector is facing many constraints such as lack of human resources, frequent fluctuation of prices, problems related to the food safety management certifications, management of natural resources in sustainable manner, impact on climate change etc. There is ample evidence to suggest that Sri Lanka's climate has been changed. Time series of annual mean temperature anomalies from 1871 - 1990 show a significant warming trend at most places in the country during the latter half of this period. The rate of increase in temperature from 1961 to 1990 is $0.016{ }^{0} \mathrm{C}$ per year (Chandrapala, 1996a; Chandrapala, 1996b; Fernando and Chandrapala, 1992). Sri Lanka's 100 year warming trend from 1896 - 1996 is 0.003 ${ }^{0} \mathrm{C}$ per year. This warming trend is seen throughout the country and could be due to enhanced greenhouse effect and 'local heat island effect' caused by rapid urbanization and land use changes (Basnayake et al., 2003; Emmanuel, 2001; Fernando and Basnayake, 2002). There is no significant trend in Sri Lanka's mean annual precipitation change during the last century although higher variability is evident (Jayatillake et al., 2005).

Tea is grown as a rainfed plantation crop in Sri Lanka. The changes in rainfall and temperature conditions directly affect tea production. The optimum temperature and rainfall for cultivation of tea are in the range of $18-22{ }^{\circ} \mathrm{C}$ and 223 to $417 \mathrm{~mm}$ per month, respectively (Wijeratne et al., 2007). Reduction of rainfall by $100 \mathrm{~mm}$ per month was found to reduce the productivity by $30-80 \mathrm{~kg}$ of 'made' tea/ha/month (Wijeratne et al., 2007). The decline of tea production due to the drought in 1992 was about 26\% compared to that of 1991 (Central Bank of Sri Lanka, 1992). Extreme events of heavy rains cause severe soil erosion. Stocking (1992) presented erosion hazard ratings developed based on the type of tea cultivation and land slope classes in the central hilly region (The catchment area of major rivers). Under these circumstances, the tea industry in Sri Lanka, especially the Nuwara Eliya district is highly vulnerable to change of climate. It may cause greater economic, social, and environmental problems.

Vulnerability to climate change can be expressed as a function of exposure, sensitivity and adaptive capacity (IPCC, 2001). Advanced modeling capabilities of 
Geographic Information Systems (GIS) are used extensively in vulnerability mapping. Limited attempts have been made so far to identify agriculturally vulnerable hot spots within Sri Lanka. Therefore, vulnerability mapping is very essential to design specific adaptation mechanisms to minimize negative impacts of climate change. It also facilitates for future planning purposes in tea industry, ensuring sustainability of the tea sector in the future as well.

The purpose of this study was to identify current vulnerability of tea sector in the major tea growing district of Nuwara Eliya in the central hilly region of Sri Lanka for climate change using four parameters, namely; monthly rainfall, monthly mean temperature, drought conditions, and soil erosion. The specific objectives were to map the variability of those four parameters separately and to develop a composite map of vulnerability of tea sector to climate change in the study area.

\section{Methodology}

\section{Study Area}

The study was carried out in Nuwara Eliya district of the Upper Mahaweli Catchment area located in central hilly region of Sri Lanka. The location map of the study area is depicted in Figure 1. The study area belongs to rainfall categories of Wet (>2500 $\mathrm{mm}$ annual rainfall) and Intermediate $(1750-2500 \mathrm{~mm}$ annual rainfall) and elevation categories of low ( $<300 \mathrm{~m}$ above mean sea level (msl)), mid (300-900 $\mathrm{m}$ above msl) and up country ( $>900 \mathrm{~m}$ above $\mathrm{msl}$ ) which was further categorized into fourteen different agro-ecological regions (Department of Agriculture, 2003).

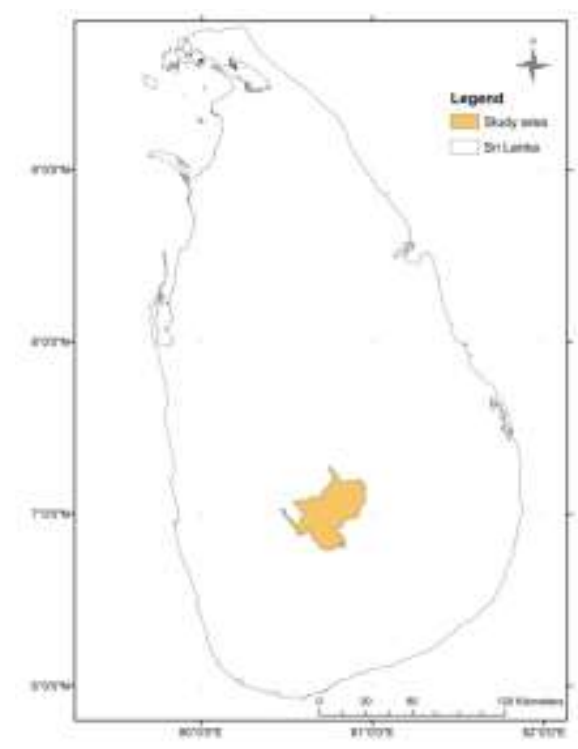

Figure 1: The location map of the study areaNuwara Eliya district of the Upper Mahaweli Catchment 


\section{Preparation of Rainfall and Temperature Maps of the Study Area}

The daily rainfall data of 41 recording stations in and around the Nuwara Eliya district were collected from the Department of Meteorology and Natural Resources Management Centre of the Department of Agriculture. Monthly averages were computed for the study period of 60 years from 1946 to 2005 .

Due to limited number of weather stations that record temperature in the study area, island wide temperature recording stations were selected. The Global Positioning System (GPS) locations of those weather stations were used to create a point data layer in the GIS environment. In case of temperature, thematic maps were produced for monthly mean temperature for the study period of 60 years from 1946 to 2005.

Out of different methods available to interpolate point data, the Inverse Distance Weighted (IDW) method was used. The spatial analysis toolbox was used for this purpose. The properties of ArcGIS 9.2 (Arc/Info) software were set as follows; power as two (2), search radius type as variable and output cell size as $100 \mathrm{~m}$.

\section{Determination of Drought Index}

Drought severity classification in Yala season (south west monsoon and first intermonsoon rainy seasons lasting from March to August) and Maha season (north east monsoon and second inter-monsoon rainy seasons lasting from September to February) seasons was identified using a drought index based on Moisture Availability Index (MAI). MAI is the ratio of the dependable rainfall to potential evapotranspiration. The potential evapotranspiration data were also collected from Department of Meteorology and Natural Resources Management Centre of the Department of Agriculture. A value of MAI less than or equal to 0.33 is considered as a very dry condition and not suited for rain fed agriculture (Hargreaves, 1975).

\section{Preparation of Erosion Hazard Maps}

Stocking (1992) presented erosion hazard ratings for different land uses in the hilly region of the Upper Mahaweli Catchment. It was emphasized that these ratings are dimensionless. Erosion hazard ratings were allocated according to the tea category (based on canopy thickness) and the land slope classes. Following classification of soil erosion was adopted in this study (Table 1).

Table 1: Soil erosion categories adopted in the study (Stocking, 1992)

\begin{tabular}{cc}
\hline Erosion Hazard Rating & Soil Erosion \\
\hline $0.05-1$ & Low \\
$2-8$ & Moderate \\
$>8$ & High \\
\hline
\end{tabular}




\section{Development of Climate Vulnerability Map}

The weighted overlaying technique which is available in GIS was used for this purpose. Four major variables were used to develop the climate vulnerability map. The main variables included in the model were mean monthly temperature, mean monthly rainfall, agricultural drought and soil erosion (Figure 2). The weightages were allocated to main variables in the model according to the influence of each variable on tea yield (Productivity). The expert scientist's views from Tea Research Institutes, University of Peradeniya and Department of Agriculture of Sri Lanka were taken by conducting an opinion survey. Once the weightages were allocated to main variables, ranking was done for sub-variables from 1 to 9 (1 was allocated for the best suited condition while 9 allocated for the worst (Highly vulnerable) condition) (Annexure 1). Statistics were generated using GIS, with respect to Divisional Secretary (DS) and Grama Niladari (GN) divisions to identify climate vulnerable tea land categories. Grama Niladari divisions are the smallest administrative unit in Sri Lanka.

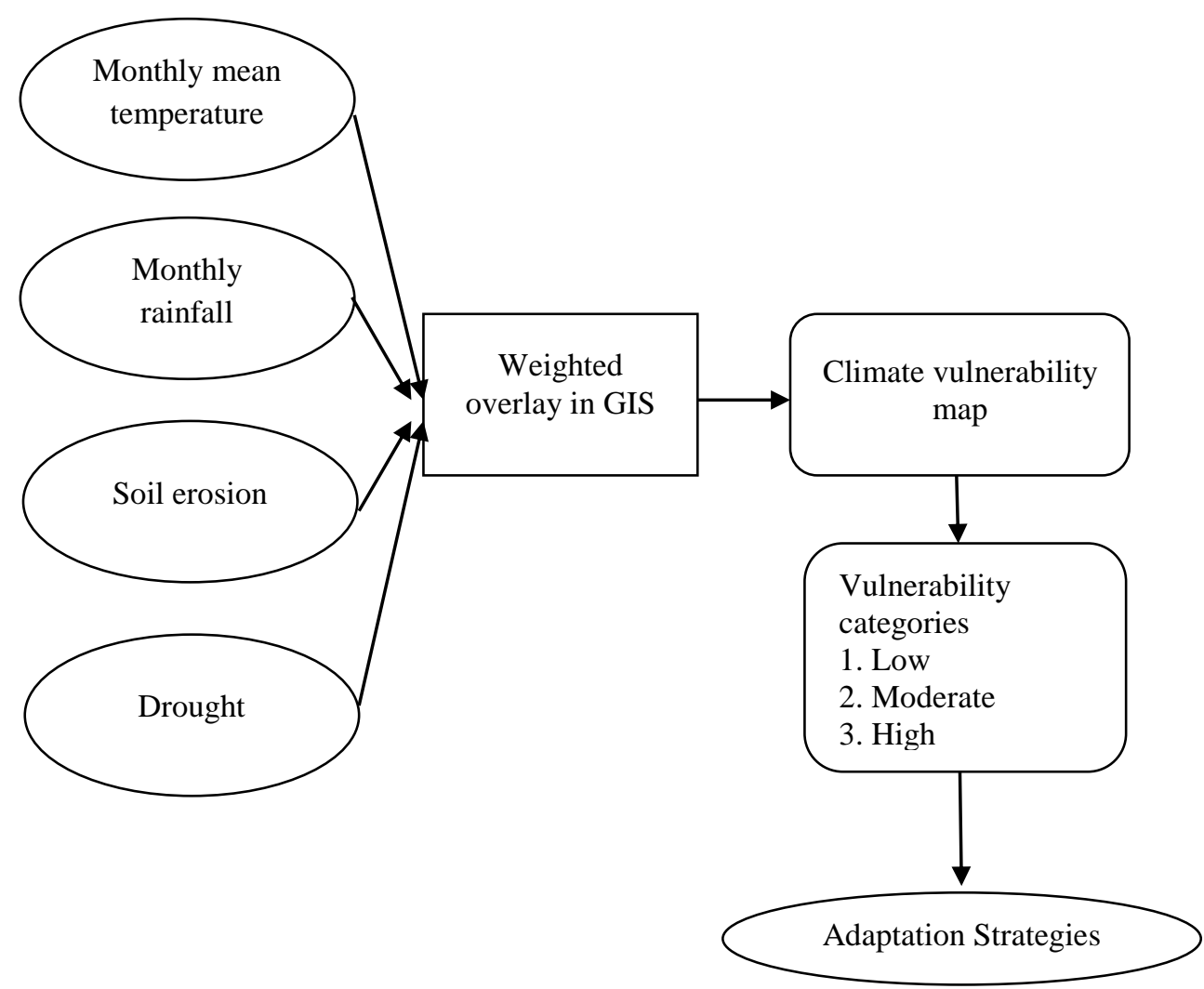

Figure 2: Main variables and model pathway used for climate vulnerability mapping 


\section{Results and Discussion}

\section{Spatio-Temporal Changes of Rainfall within Nuwara Eliya District}

Nuwara Eliya district consists of Wet (>2500 $\mathrm{mm}$ annual rainfall) and Intermediate (1750-2500 mm annual rainfall) climatic conditions. The district receives rains from all four rainy seasons with a varying spatial distribution. The summary of the results derived from the spatio-temporal analysis of the rainfall is given in Table 2 .

Spatial variations of rainfall (1946 to 2005) for the twelve months are depicted in Figure 3. Rainfall data analysis for the study period revealed that months of January, June, July and August were having high rainfall variability, which emphasis the need for special attention to reduce negative impacts.

Table 2: Summary of the spatial analysis of mean monthly rainfall (1946 to 2005) in Nuwara Eliya district

\begin{tabular}{ccccc}
\hline Month & $\begin{array}{c}\text { Minimum } \\
\text { Rainfall }(\mathbf{m m})\end{array}$ & $\begin{array}{c}\text { Maximum } \\
\text { Rainfall }(\mathbf{m m})\end{array}$ & $\begin{array}{c}\text { Mean Rainfall } \\
(\mathbf{m m})\end{array}$ & $\begin{array}{c}\text { CV } \\
(\boldsymbol{\%})\end{array}$ \\
\hline January & 65 & 423 & 194 & 55 \\
February & 60 & 207 & 116 & 35 \\
March & 70 & 268 & 121 & 16 \\
April & 149 & 359 & 229 & 12 \\
May & 103 & 620 & 204 & 39 \\
June & 44 & 810 & 242 & 63 \\
July & 66 & 673 & 225 & 55 \\
August & 69 & 618 & 203 & 53 \\
September & 99 & 627 & 207 & 42 \\
October & 232 & 654 & 305 & 19 \\
November & 214 & 405 & 304 & 43 \\
December & 119 & 553 & 270 & \\
\hline
\end{tabular}

$\overline{C V-C o e f f i c i e n t ~ o f ~ V a r i a t i o n ~}$

Minimum rainfall requirement for tea is considered as $100 \mathrm{~mm} / \mathrm{month}$ (Watson, 2008). Months of January, February, March, June, July and August were recorded less than the minimum rainfall level in some parts of the study region. 


\section{Spatio-Temporal Changes of Temperature within Nuwara Eliya District of the Upper Mahaweli Catchment}

Spatial variations of mean temperature (1946 to 2005) for the twelve months are depicted in Figure 4. Tea grows well within a temperature range of $18-25^{\circ} \mathrm{C}$, and an air temperature below $13{ }^{\circ} \mathrm{C}$ and above $30{ }^{\circ} \mathrm{C}$ is found to reduce growth (Watson, 2008). Some parts of the study area were experiencing below $13{ }^{\circ} \mathrm{C}$ temperature, except months of April and May.

Most parts of the study area possess an ideal temperature $\left(18-25^{\circ} \mathrm{C}\right)$ for growth of tea. Results revealed that $64.47 \%$ of the land extent comes within the mean annual temperature range of 18 to $25^{\circ} \mathrm{C}$, which considered as an ideal temperature range for growth of tea (Table 3).

Table 3: Mean annual temperature classes in Nuwara Eliya district

\begin{tabular}{ccc}
\hline Temperature Classes $^{\mathbf{}} \mathbf{C}$ & Land Extent (ha) & Percentage (\%) \\
\hline 12 to 15 & 6,160 & 4.82 \\
15 to 18 & 35,279 & 27.60 \\
18 to 25 & 82,406 & 64.47 \\
25 to 27 & 3,976 & 3.11 \\
\hline Total & 127,820 & 100 \\
\hline
\end{tabular}

\section{Identification of Drought Prone Regions in Nuwara Eliya District}

Drought severity classification in Yala and Maha seasons was identified using drought index based on moisture availability index (MAI) (Table 4) as described in Chithranayana and Punyawardena (2008).

Table 4: Drought severity classification (Hargreaves, 1975)

\begin{tabular}{cc}
$\begin{array}{c}\text { No. of Months with MAI } \\
\text { Less Than or Equal to 0.34 }\end{array}$ & Drought Severity \\
\hline 0 & Wet \\
1 & Slightly wet \\
2 & Mild drought \\
3 & Drought \\
4 or more & Severe drought \\
\hline
\end{tabular}




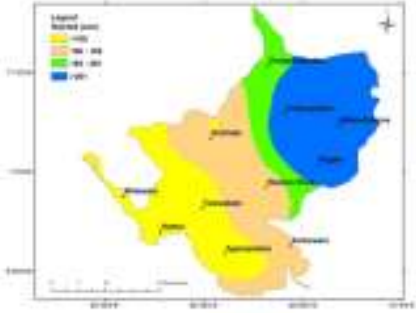

$\mathrm{a}$

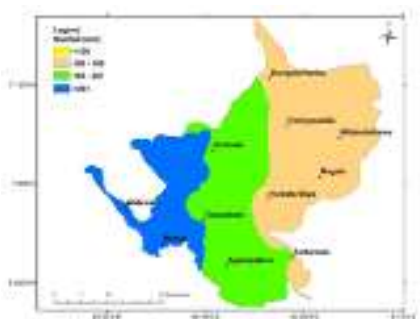

e

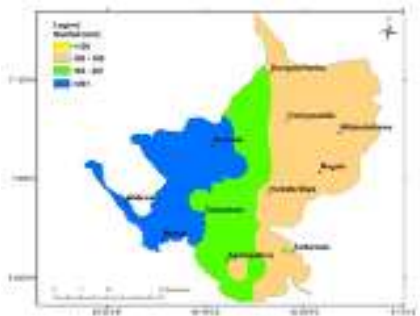

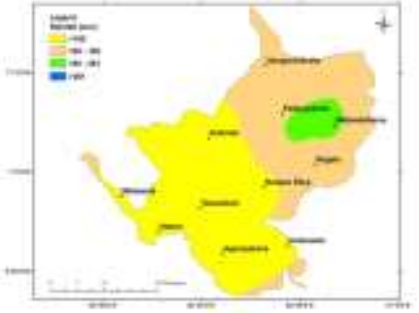

b
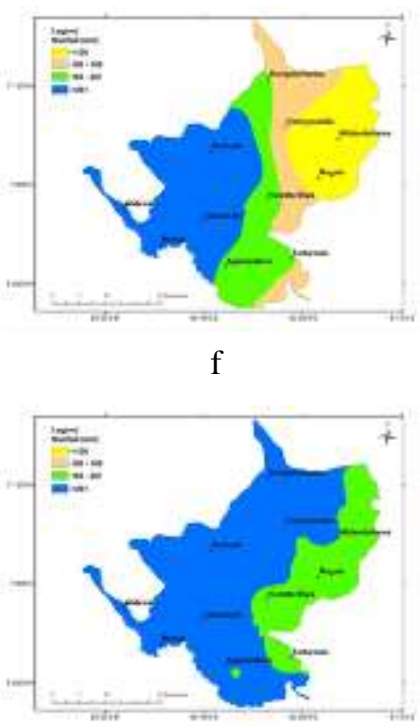

$\mathrm{j}$
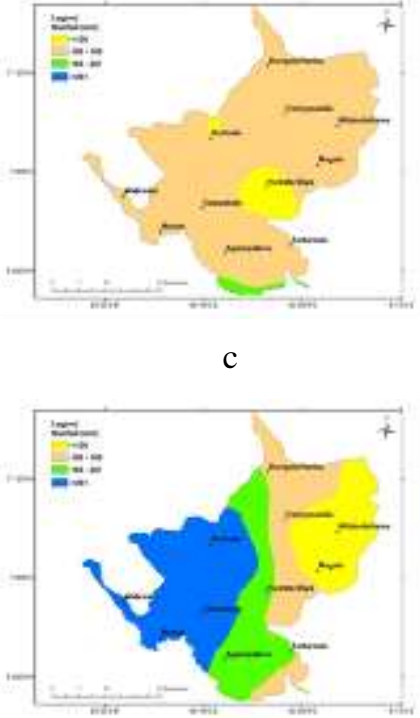

$\mathrm{g}$

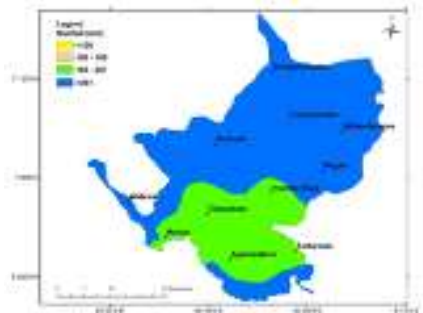

k
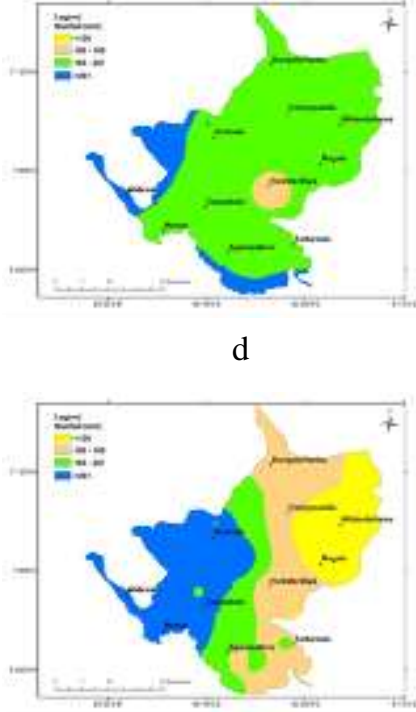

$\mathrm{h}$

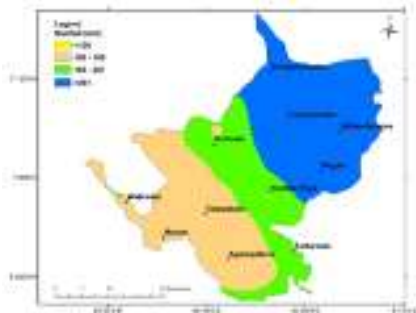

1

Figure 3: Spatial variation of mean monthly rainfall for the period from 1946-2005 (a) January; (b) February; (c) March; (d) April; (e) May; (f) June; (g) July; (h) August; (i) September; (j) October; (k) November and (l) December 


\section{Identification of Drought Prone Regions in Nuwara Eliya District}

Drought severity classification in Yala and Maha seasons was identified using drought index based on moisture availability index (MAI) (Table 4) as described in Chithranayana and Punyawardena (2008).

Table 4: Drought severity classification (Hargreaves, 1975)

\begin{tabular}{cc}
\hline $\begin{array}{c}\text { No. of Months with MAI } \\
\text { Less Than or Equal to 0.34 }\end{array}$ & Drought Severity \\
\hline 0 & Wet \\
1 & Slightly wet \\
2 & Mild drought \\
3 & Drought \\
4 or more & Severe drought \\
\hline
\end{tabular}

\section{Spatial Pattern of Drought during Maha Season}

The spatial distribution of the drought during Maha Season in Nuwara Eliya district is depicted in Figure 5. All the agro ecological regions in the study area were free from drought hazards during Maha seasons due to the relatively high effectiveness of Second Inter Monsoon rains and low evapotranspiration rates over all agroecological regions (Table 5).

\section{Spatial Pattern of Drought during Yala Season}

The spatial distribution of the drought during Yala Season in Nuwara Eliya district is depicted in Figure 6. Agro-ecological regions in the Up country Intermediate zone (IU) of IU $3 b$ and IU3e experience a mild drought conditions compared to wetter regions. However, agro ecological regions in the Mid country Intermediate zone (IM) of IM1a and IM3c are vulnerable to mild drought and drought conditions, respectively (Table 6). Under such situations, tea cultivation is highly vulnerable to water shortage conditions during Yala season in above agro ecological regions.

For relatively high drought prone areas, drought tolerant varieties can be used. Planting of shade trees to reduce the drought impacts in IU regions is important (Wijeratne et al., 2007). 

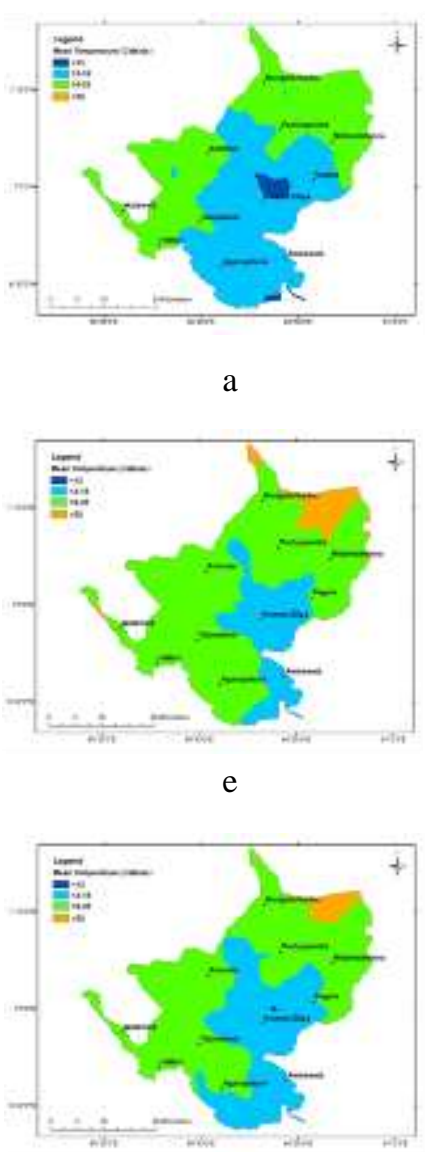

i

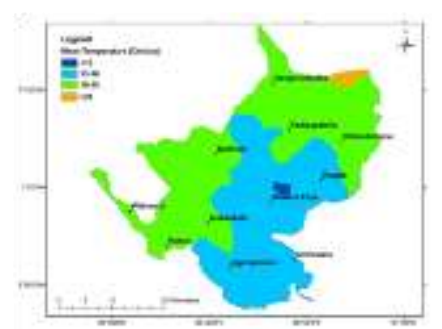

b

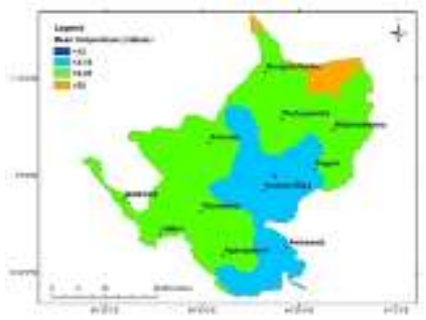

f

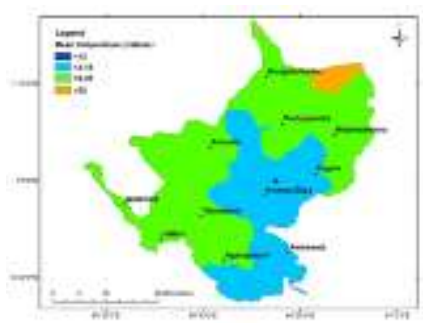

j

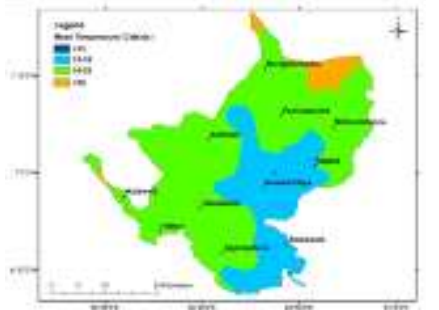

c

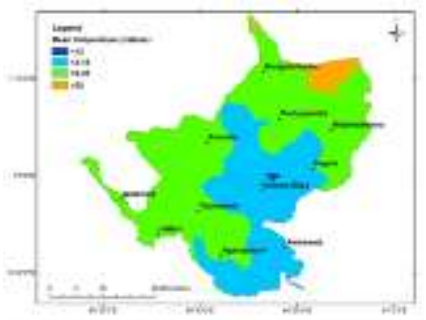

g

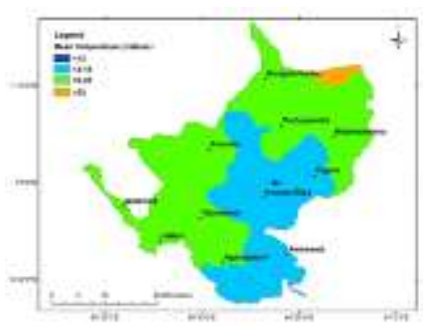

$\mathrm{k}$

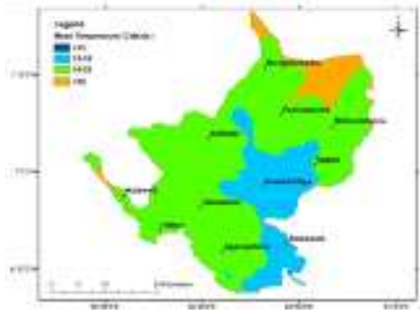

d

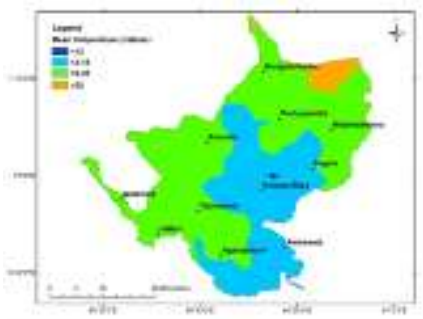

h

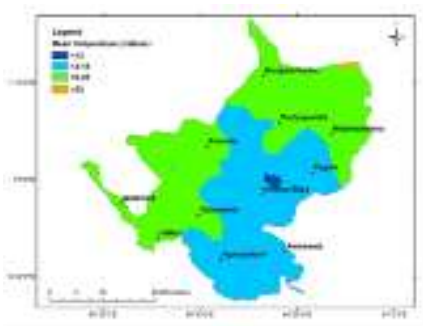

1

Figure 4: Spatial variation of average monthly mean temperature from 1946 to 2005 (a) January; (b) February; (c) March; (d) April; (e) May; (f) June; (g) July; (h) August; (i) September; (j) October; (k) November and (l) December 
Table 5: Drought severity of each agro ecological region during Maha season (Chithranayana and Punyawardena, 2008)

\begin{tabular}{ccc}
\hline Agro Ecological Region & Drought Severity & Dry Months \\
\hline IL2 (Low country Intermediate) & Wet & \\
IM1a (Mid country Intermediate) & Wet & \\
IM1c (Mid country Intermediate) & Wet & Wet \\
IM3c (Mid country Intermediate) & Wet & \\
IU2 (Up country Intermediate) & Wet & \\
IU3b (Up country Intermediate) & Wet & February \\
IU3d (Up country Intermediate) & Wet & \\
IU3e (Up country Intermediate) & Wet & \\
WM1a (Mid country Wet) & Slightly wet & \\
WM2a (Mid country Wet) & Wet & \\
WU1 (Up counter Wet) & Wet & \\
WU2a (Up counter Wet) & Wet & \\
WU2b (Up counter Wet) & Wet & \\
WU3 (Up counter Wet) &
\end{tabular}

Table 6: Drought severity of each agro ecological region during Yala season (Chithranayana and Punyawardena, 2008)

\begin{tabular}{ccc}
\hline Agro Ecological Region & Drought Severity & Dry Months \\
\hline IL2 (Low country Intermediate) & Severe Drought & June, July, August, March \\
IM1a (Mid country Intermediate) & Mild Drought & June, July \\
IM1c (Mid country Intermediate) & Drought & June, July, August \\
IM3c (Mid country Intermediate) & Drought & June, July, August \\
IU2 (Up country Intermediate) & Wet & \\
IU3b (Up country Intermediate) & Mild Drought & June, July \\
IU3d (Up country Intermediate) & Slightly Wet & June \\
IU3e (Up country Intermediate) & Mild Drought & \\
WM1a (Mid country Wet) & Wet & \\
WM2a (Mid country Wet) & Wet & \\
WU1 (Up counter Wet) & Wet & \\
WU2a (Up counter Wet) & Wet & \\
WU2b (Up counter Wet) & Wet & \\
WU3 (Up counter Wet) & Wet & \\
\hline
\end{tabular}




\section{Soil Erosion Map for Tea Lands in Nuwara Eliya District}

To determine soil erosion, erosion hazard ratings which were discussed by Stocking (1992) were used in this study. Results revealed that $3.96 \%$ of the tea extent is highly vulnerable to soil erosion (Table 7). The soil erosion map in tea lands for Nuwara Eliya district is depicted in Figure 7.

Table 7: Tea extent under different soil erosion classes in Nuwara Eliya district

Soil Erosion Class

\begin{tabular}{rcc}
\hline Low & 31,658 & 79.64 \\
Moderate & 6,519 & 16.40 \\
High & 1,574 & 3.96 \\
\hline Total & 39,751 & 100 \\
\hline
\end{tabular}

Tea lands with less canopy cover were highly vulnerable for soil erosion. Soil erosion is high in poorly managed seedling tea fields (poor ground cover) compared to vegetatively - propagated (good ground cover) tea.

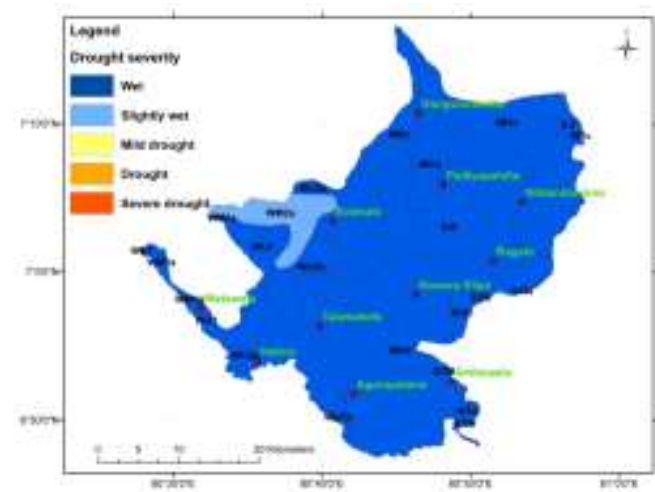

Figure 5: Spatial pattern of drought during Maha Season in the study area

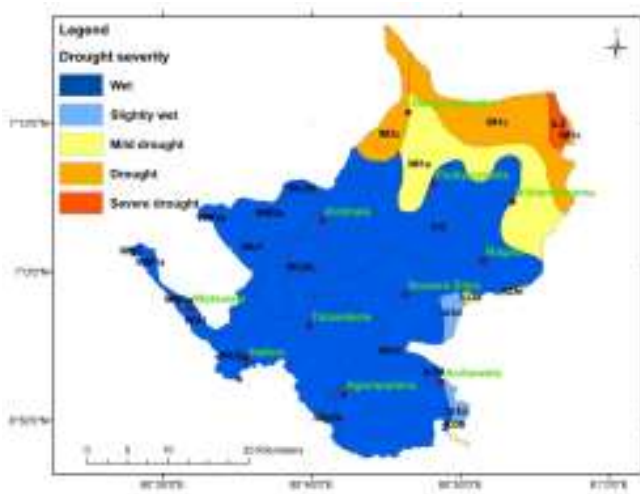

Figure 6: Spatial pattern of drought during Yala Season in the study area

Poorly managed seedling tea fields have more open patches which are conducive to soil erosion. Therefore, special emphasize should be given to tea lands in steep slope regions where seedling tea is grown. The area which was identified as highly vulnerable should be given more emphasis on soil erosion and soil moisture conservation measures. Biological strategies such as soil rehabilitation, Slopping Agricultural Land Technology (SALT), cover crops and infilling of tea lands to improve ground cover can be recommended (Wijeratne et al., 2007; Wijeratne, 2009). Implementation of good agricultural practices (GAP) ensures the sustainability of the tea cultivation in the Nuwara Eliya district. 


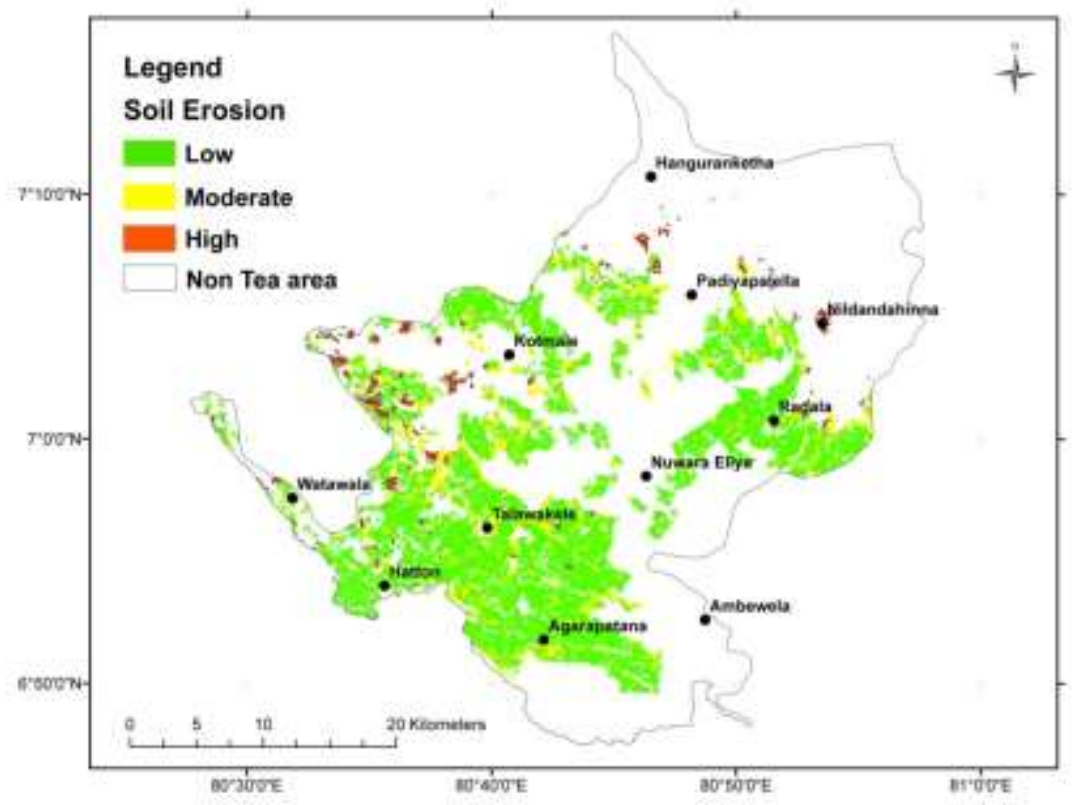

Figure 7: The soil erosion map for Nuwara Eliya district of the Upper Mahaweli Catchment

\section{Climate Vulnerability Modeling}

Climate vulnerability map was derived combining the mean monthly rainfall, mean annual temperature, agricultural drought vulnerability and soil erosion vulnerability. In this analysis, weighted overlaying technique was used to derive climate vulnerability map. In order to allocate appropriate weightages for main variables, an opinion survey was carried out with 25 scientists from Tea Research Institute (Talawakelle, Rathnapura, Hanthana), Department of Agriculture (Natural Resources Management Centre) and Crop Science Department (University of Peradeniya). The summary results of the opinion survey are given in Table 8 .

Table 8: Summary of the opinion survey on proportional weightage allocation for major variables on the influence on tea production

\begin{tabular}{cc}
\hline Variable & $\begin{array}{c}\text { Percentage }(\%) \text { of Weightage } \\
\text { out of Total 100 Points }\end{array}$ \\
\hline Mean monthly Rainfall $(\mathrm{mm} /$ month $)$ & 35 \\
Mean annual temperature $\left({ }^{\circ} \mathrm{C}\right)$ & 10 \\
Agricultural drought & 10 \\
Soil erosion & 45 \\
\hline Total & 100 \\
\hline
\end{tabular}


The climate vulnerability map developed based on combination of individual vulnerabilities of rainfall, temperature, agricultural drought, and soil erosion in Nuwara Eliya district was categorized into three broad classes as less vulnerable, moderately vulnerable and highly vulnerable (Figure 8). The Climate vulnerability map revealed that 5,225 ha $(13.15 \%)$ of tea land extent in the region was highly susceptible for current climate vulnerability. Most of the seedling tea lands (propagated using seedlings) which have less than 40\% ground cover (1677 ha) were categorized in to the highly climate vulnerable category. Soil erosion was given the highest weightage in the model (45\%), because it has become the major limiting factor in up country tea production. Furthermore, tea land extent of 8,165 ha $(20.54 \%)$ and 26,361 ha $(66.31 \%)$ were categorized as moderately and less climate vulnerable, respectively (Table 9).

Table 9: Summary of the climate vulnerability classes identified based on combination of individual vulnerabilities of rainfall, drought, soil erosion and temperature

\begin{tabular}{ccc}
\hline Climate Vulnerability Classes & Tea Extent (ha) & Percentage (\%) \\
\hline Low & 26,361 & 66.31 \\
Moderate & 8,165 & 20.54 \\
High & 5,225 & 13.15 \\
\hline Total & 39,751 & 100 \\
\hline
\end{tabular}

Distribution of the vulnerable tea classes with respect to Divisional Secretary Divisions (DSD) are given in the Table 10. The results revealed that the highest percentages of highly vulnerable tea extent were distributed in Nuwara Eliya DS division. Distribution of the vulnerable tea classes with respect Grama Niladari (GN) divisions are given in Table 11.

Table 10: Distribution of the climate vulnerable tea classes with respect to Divisional Secretary Divisions (DSD)

\begin{tabular}{cccc}
\hline \multirow{2}{*}{ DSD } & \multicolumn{3}{c}{ Climate Vulnerability (ha) } \\
\cline { 2 - 4 } & Low & Moderate & High \\
\hline Ambagamuwa & 1956 & 213 & 79 \\
Hanguranketha & 1836 & 837 & 170 \\
Kothmale & 5884 & 1900 & 854 \\
Nuwara Eliya & 12966 & 4100 & 2696 \\
Walapane & 3719 & 1115 & 1426 \\
\hline
\end{tabular}


A few climate vulnerability modeling studies have been carried out in order to assess the climate vulnerability in Sri Lanka. Composite vulnerability index for multi-hazard exposure for each district in Sri Lanka have been developed and results showed that Nuwara Eliya distrct was ranked as 80-100 (high vulnerable) range (Eriyagama et al., 2010). Composite vulnerability indices for drought, flood and cyclone also showed that Nuwara Eliya district was considered as highly vulnerable compared to other districts in Sri Lanka (Eriyagama et al., 2010). Climate vulnerability modeling studies related to crops and forestry have used geographic information systems and remote sensing as a modeling tool (Omo-Irabor et al., 2011, Zhang et al., 2006). In this study only the physical vulnerability was assessed with respect to Tea lands. Several climate vulnerability studies have considered the social vulnerability in vulnerability modeling (Eriyagama et al., 2010; O'Brien et al., 2004). In this study only the potential climate vulnerability was assessed. Adaptive capacity was not considered in vulnerability modeling.

With anticipated climate change in future, moderately vulnerable areas can also become highly vulnerable. Therefore, appropriate adaptation strategies should be taken immediately to protect those lands to avoid further degradation.

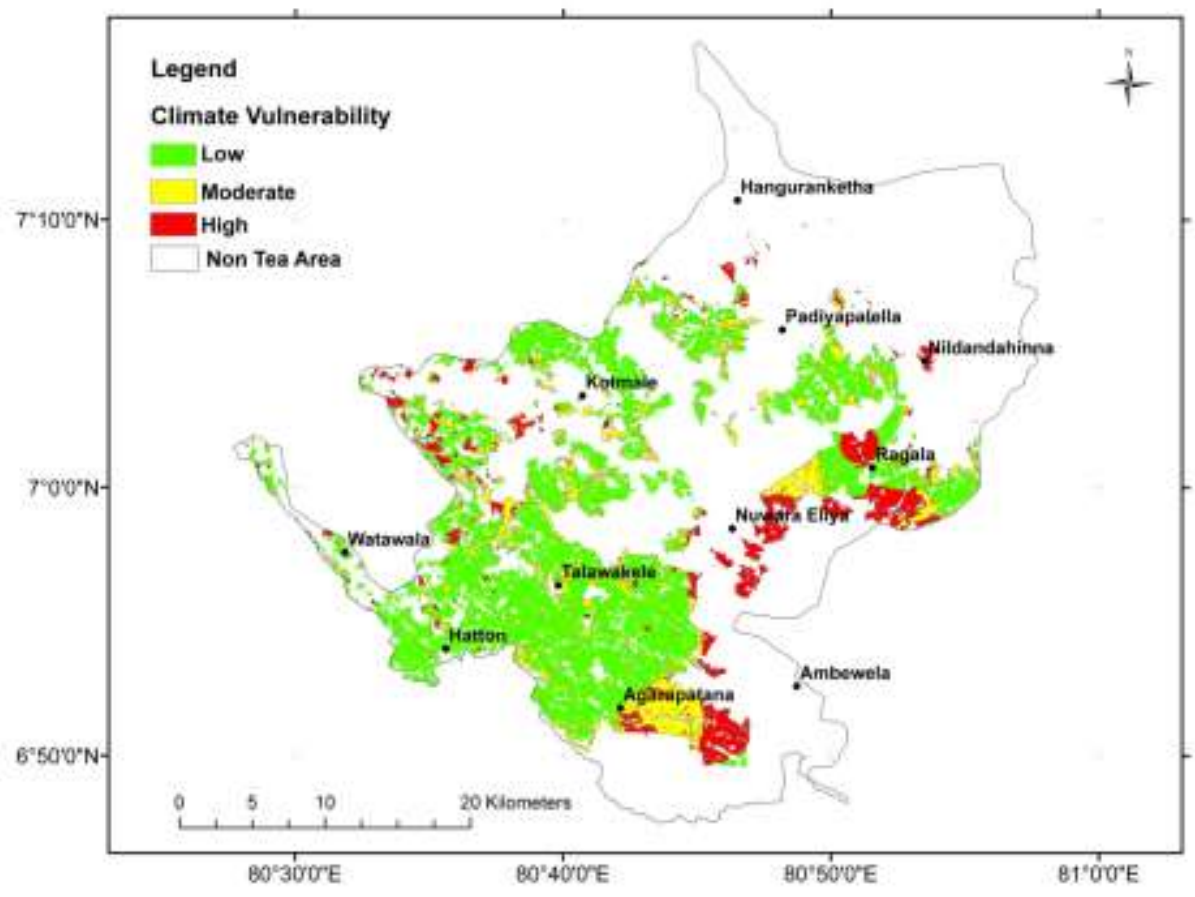

Figure 8: The potential climate vulnerability map for Nuwara Eliya district of the Upper Mahaweli Catchment 


\section{Table 11: GN (Grama Niladari) divisions in Nuwara Eliya district under different climate vulnerable classes}

\begin{tabular}{|c|c|c|}
\hline \multicolumn{3}{|c|}{ Climate Vulnerability Classes } \\
\hline Less & Moderate & High \\
\hline Coombewood & Glasgow & Sandrinhem \\
\hline Albian & Park & Delmar \\
\hline Nagasena & Weverly & Dayagama West \\
\hline Waltrim Watta & Dayagama West & Rathnayakapura \\
\hline Hope Estate & Hope Estate & Brookside \\
\hline Highforest Watta & Lipakele & Pedro \\
\hline Eldonhall & Sandrinhem & Ruwaneliya \\
\hline Stonycliff & Rukwood Estate & Dayagama East \\
\hline Kirimetiya & Concordia & Concordia \\
\hline Shanon & Agarapathana & Ketambulawa \\
\hline Yulefield & Sheen Estate & Park \\
\hline Dreton & Udapussellawa South & Agarapathana \\
\hline Dunsinan & Barewell & Udapussellawa South \\
\hline Frotoft & Rahanwatta & St. Leonard \\
\hline Great Western & Medakumbura North & Lipakele \\
\hline Brookside & Dunukedeniya & Ruwanpura \\
\hline Balmoral & Kurunduoya & Sandathenna \\
\hline Elbedda & Elbedda & Nildandaheenna \\
\hline Kudu Oya & Kolapathana & Glasgow \\
\hline Bangalahatha & Palagolla & Perakumpura \\
\hline Watagoda & Great Western & Thelissagama \\
\hline Summerset & Hollyrood & Bulu Ela \\
\hline Medakumbura North & Binganthalawa & Sooriyagaha Pathana \\
\hline Bremore & Labukele & Samagipura \\
\hline Helboda & Perakumpura & Bangalahatha \\
\hline Lindula & Kudu Oya & Nuwaraeliya Central \\
\hline Barewell & Watagoda & Bogahawatta \\
\hline Wedamulla & Summerset & Nuwaraeliya West \\
\hline Kurunduoya & Lindula & Kalapura \\
\hline Binganthalawa & Gonapitiya Watta & Katarandana \\
\hline Henfold & Albian & \\
\hline Perakumpura & Coombewood & \\
\hline Rosella & St. Magret & \\
\hline St. Magret & Wedamulla & \\
\hline Rahanwatta & Pundaluoya North & \\
\hline Dimbula & Dunsinan & \\
\hline Muloya & Watawala & \\
\hline Thangakele Watta & Senarathpura & \\
\hline Bogahawatta & Maha Uva & \\
\hline Ketambulawa & Sooriyagaha Pathana & \\
\hline Sheen Estate & Mount Vernon & \\
\hline Karagasthalawa & Muloya & \\
\hline
\end{tabular}




\section{Conclusions}

Rainfall data analysis for the study period revealed that months of January, June, July and August were having high rainfall variability, which emphasis the need for special adaptation attention to reduce climate change impacts tea production. Around $65 \%$ of land extent of the study area is possessed an ideal temperature (18$25{ }^{\circ} \mathrm{C}$ ) for growth of tea. The entire study area does not exhibit droughts during Maha season. However, in almost all agro-ecological regions of the Up country Intermediate zone, the drought proneness is relatively higher, except IU2, during the Yala season. There is also a slight possibility of drought conditions occurring in the Wet zone of the study area during Yala season.

Land extent of 1,574 ha $(3.96 \%)$ under tea was highly vulnerable for soil erosion in the study area. Less and moderate soil erosion vulnerable tea extent were 31,658 ha $(79.64 \%)$ and 6,519 ha $(16.40 \%)$, respectively.

Overall climate vulnerability mapping considering all four variables revealed that 5,225 ha $(13.15 \%)$ tea extents were considered as highly susceptible for current climate vulnerability which requires urgent attention. Furthermore, tea land extent of 8,165 ha $(20.54 \%)$ and 26,361 ha $(66.31 \%)$ were categorized as moderately and less climate vulnerable, respectively could also become vulnerable in the future if appropriate improvement programs are not implemented.

\section{References}

Basnayake, B. R. S. B., B. V. R. Punyawardena and J. C. Vithanage (2003). "An investigation of ambient air temperature trends at Hambantota - Angunakolapelassa and Nuwara Eliya - Thalawakele". Proceedings of the 59 ${ }^{\text {th }}$ Annual Session of Sri Lanka Association for the Advancement of Science (SLASS). Section E1. pp 194.

Central Bank of Sri Lanka (1992). Annual Report, Colombo, Sri Lanka.

Central Bank of Sri Lanka (2013). Annual Report, Colombo, Sri Lanka.

Chandrapala, L. (1996a). "Calculation of areal precipitation of Sri Lanka on district basis using Voronoi Tessalation Method". Proceedings of National Symposium on Climate Change. Central Environmental Authority, Colombo, Sri Lanka, March 7-8, 1996.

Chandrapala, L. (1996b). "Long term trends of rainfall and temperature in Sri Lanka". In: Abrol, Y. P., S. Gadgil and G. B. Pant (Eds.). Climate Variability and Agriculture, Narosa Publishing House, New Delhi, India pp 153-162.

Chithranayana, R. D. and B. V. R. Punyawardena (2008). "Identification of drought prone agro-ecological regions in Sri Lanka". Journal of the National Science Foundation of Sri Lanka. 36, 117-123.

Department of Agriculture (2003). "Agro-ecological regions of Sri Lanka". Department of Agriculture, Peradeniya, Sri Lanka. 
Emmanuel, R. (2001). "The thermal comfort effects of urbanization: bio-climatic and landuse changes in the Colombo Metropolitan Region (CMR)". Proceedings of the 57th Annual Session of Sri Lanka Association for the Advancement of Science (SLASS). Section C, pp. 113.

Eriyagama, N., V. Smakhtin, L. Chandrapala and K. Fernando (2010). "Impacts of climate change on water resources and agriculture in Sri Lanka: a review and preliminary vulnerability mapping". IWMI research report 135, International Water Management Institute, Colombo, Sri Lanka.

Fernando, T. K. and B. R. S. B. Basnayake (2002). "A comparative study of the ambient air temperature at Anuradhapura and Mahailluppallama”. Proceedings of the $58^{\text {th }}$ Annual Session of Sri Lanka Association for the Advancement of Science (SLASS). Section E1, pp. 213.

Fernando, T. K. and L. Chandrapala (1992). "Global warming and rainfall variability - Sri Lankan Situation". Proceedings of the $47^{\text {th }}$ Annual Session of Sri Lanka Association for the Advancement of Science (SLASS). Section E1, pp. 138.

Hargreaves, G. H. (1975). "Moisture availability and crop production". Transactions of the ASAE. 18(5), 980-984.

IPCC (2001). "Climate change 2001: Impacts, adaptation, and vulnerability". Contribution of Working Group II to the Third Assessment Report of the Intergovernmental Panel on Climate Change. In: McCarthy, J., O. Canziani, N. Leary, D. Dokken and K. White (Eds.). Cambridge, UK: Cambridge University Press.

Jayatillake, H. M., L. Chandrapala, B. R. S. B. Basnayake and G. H. P. Dharmaratne (2005). "Water resources and climate change". In: Wijesekera, N. T. S., K. A. U. S. Imbulana and B. Neupane (Eds.). Proceedings of Workshop on Sri Lanka National Water Development Report. World Water Assessment Programme (WWAP), Paris, France.

O'Brien, K., R. Leichenkob, U. Kelkarc, H. Venemad, G. Aandahla, H. Tompkinsa, A. Javedc, S. Bhadwalc, S. Bargd, L. Nygaarda and J. West (2004). "Mapping vulnerability to multiple stressors: climate change and globalization in India". Global Environmental Change 14, $303-313$.

Omo-Irabor, O. O., S. B. Olobaniyi, J. Akunna, V. Venus, J. M. Maina and C. Paradzayi (2011). "Mangrove vulnerability modelling in parts of Western Niger Delta, Nigeria using satellite images, GIS techniques and Spatial Multi-Criteria Analysis (SMCA)". Environmental monitoring and assessment, 178 (1-4), 39-51.

Plantation Sector Statistical Pocket Book (2012). Planning division, Ministry of Plantation Industries, Colombo, Sri Lanka.

Stocking, M. (1992). "Soil erosion in the Upper Mahaweli Catchment". Technical report No. 14, Environment and forestry division, Mahaweli Authority of Sri Lanka, Polgolla.

Watson, M. (2008). “Climatic requirements and soil”. In: Zoysa, A. K. N. (Eds.). Handbook on Tea, Tea Research Institute of Sri Lanka, Talawakelle, Sri Lanka, pp. 10 - 15. 
Wijeratne, M. A. (2009). "Adaptation to the threats of climate change: Plantation crops with special reference to tea". In: Workshop on mainstreaming climate change for sustainable development in Sri Lanka, 19-21 August, 2009.

Wijeratne, M. A., A. Anandacoomaraswamy, M. K. S. L. D. Amarathunga, J. Ratnasiri, B. R. S. B. Basnayake and N. Kalra (2007). "Assessment of impact of climate change on productivity of tea (Camellia sinensis L.) plantations in Sri Lanka". Journal of National Science Foundation Sri Lanka, 35, 119-126.

Zhang, Q., C. O. Justice, M. Jiang, J. Brunner and D. S. Wilkie (2006). "A GIS-based assessment on the vulnerability and future extent of the tropical forests of the Congo basin". Environmental Monitoring and Assessment, 114, 107-121. 
Journal of Environmental Professionals Sri Lanka: 2015 - Vol. 4 - No. 1 -29-48

Annexure 1: Weights and ranks allocated for main variables and sub categories respectively

\begin{tabular}{cccc}
\hline Main Variable & Contribution (\%) & Sub Category & Rank \\
\hline $\begin{array}{c}\text { Mean monthly rainfall } \\
(\mathrm{mm} / \text { month) }\end{array}$ & 35 & $<100$ & 9 \\
& & $100-185$ & 6 \\
& 10 & $185-261$ & 3 \\
Monthly mean temperature $\left({ }^{0} \mathrm{C}\right)$ & & $>261$ & 1 \\
& & $<13$ & 9 \\
& \multirow{2}{*}{10} & $18-25$ & 3 \\
Agricultural drought & & $>25$ & 1 \\
& & Wlightly wet & 2 \\
& & Mild drought & 7 \\
& & Drought & 8 \\
& & Severe drought & 9 \\
\hline Soil erosion & 45 & Low & 1 \\
& & Moderate & 5 \\
& & High & 9 \\
\hline
\end{tabular}

